\title{
Mechanism of silicate elution by hydrogen sulfide from bottom sediment in a brackish lake
}

\author{
Ja Yeong Park ${ }^{1,2}\left(\right.$ D $\cdot$ Shogo Sugahara ${ }^{1} \cdot$ Michiko Egawa $^{1} \cdot$ Yasushi Seike $^{1,3}$
}

Received: 10 June 2019 / Accepted: 24 November 2019 / Published online: 7 December 2019

(c) The Author(s) 2019

\begin{abstract}
Highly concentrated dissolved silicate was detected in pore water from anoxic-reducing sediment in Lake Nakaumi, a brackish lake. Silicate concentration also simultaneously increased with total hydrogen sulfide concentration during the summer. Generally, dissolved silicate is readily adsorbed onto ferric hydroxide and precipitates in an oxidative environment. In this study, we focused on the behavior of ferric hydroxide adsorbing silicate in sediment and determined that hydrogen sulfide was the main cause of dissolved silicate elution from ferric hydroxide adsorbing silicate because the hydrogen sulfide produced via microbiological processes in the anoxic-reducing environment was reducible for other metal oxides. According to laboratory experiments, silicate was released from ferric hydroxide by reacting with sodium sulfide, causing increasing elution of dissolved silicate from anoxic-reducing sediments with increasing concentration of sodium sulfide in the solutions. This result shows that hydrogen sulfide is very crucial for silicate release under a reducing environment. Therefore, in Lake Nakaumi, silicate would be released from the bottom after ferric hydroxide adsorbing silicate reacted with hydrogen sulfide in a summer reductive environment.
\end{abstract}

Keywords Elution $\cdot$ Ferric hydroxide $\cdot$ Hydrogen sulfide $\cdot$ Reduction $\cdot$ Pore water

\section{Introduction}

Silicon is the second most abundant element in Earth's crust and typically exists as silica $\left(\mathrm{SiO}_{2}\right)$ or in silicate minerals. Dissolved silicate in a water environment is generally found as monomeric silicate $\left(\mathrm{H}_{4} \mathrm{SiO}_{4}\right)$ and is characterized by a non-ionic form in neutral and weakly acidic solutions but is ionized in an alkaline solution (Philippini et al. 2006). The ionized ratio of dissolved silicate is approximately $0.016 \%$ at a $\mathrm{pH}$ of 7 and increases with increasing $\mathrm{pH}$. This ratio is

Handling Editor: Masahiro Maruo.

Ja Yeong Park

park.jayeong.53v@gmail.com

1 Interdisciplinary Graduate School of Science and Engineering, Shimane University, 1060

Nishikawatsu-cho, Matsue-shi, Shimane 690-8504, Japan

2 Present Address: Graduate School of Human and Environmental Studies, Kyoto University, Yoshida-Nihonmatsu-cho, Sakyo-ku, Kyoto 606-8501, Japan

3 Present Address: Estuary Research Center, Shimane University, 1060 Nishikawatsu-cho, Matsue-shi, Shimane 690-8504, Japan
50 and $94 \%$ at a pH of 9 and 11, respectively (Gottlieb and Meyers 2012). Overall, the average global concentration of dissolved silicate ranges from $0.07 \mathrm{mmol} / \mathrm{L}(2 \mathrm{mg}-\mathrm{Si} / \mathrm{L})$ in the ocean (Tréguer et al. 1995) to $0.14 \mathrm{mmol} / \mathrm{L}$ (4 mg-Si/L) in rivers (Conley 1997). High concentrations of dissolved silicate [e.g., > $1.42 \mathrm{mmol} / \mathrm{L}(40 \mathrm{mg}-\mathrm{Si} / \mathrm{L})$ ] are also found in sediment pore waters (Hallmark et al. 1982).

Silicate is one of the essential nutrients used by aquatic organisms such as phytoplankton (e.g., diatoms) to form their skeletons (Perry and Keeling-Tucker 2000; Yee et al. 2003; Lacombe et al. 2007); this diatom accounts for $25 \%$ of the world's entire net primary production (Willén 1991). Diatom growth competes with dinoflagellate growth, which causes red tide (Furumai 2012). Flagellates such as dinoflagellate, chrysophyte, and chlorophyte are potentially harmful phytoplankton in nature, and when diatoms disappear, they become dominant species (Schelske and Stoermer 1971; Conley et al. 1993). Thus, silicate is a critical nutrient that may influence primary production and dominant species change of phytoplankton (Officer and Ryther 1980; Conley et al. 1993), and a comprehensive understanding of the geochemical behavior of silicate is important in aquatic science and ecology. 
Dissolved silicates are mainly supplied to lakes by rivers. A portion of this silicate is readily adsorbed onto ferric hydroxide $\left[\mathrm{Fe}(\mathrm{OH})_{3}\right]$ which is distributed in an oxidative epilimnion to form relatively insoluble siliceous ferric hydroxide particles (Vempati and Loeppert 1989; Fischer and Knoll 2009; Gottlieb and Meyers 2012). These particles are then deposited in lake-bottom sediment. If the lakebottom environment maintains oxidative properties, nearly all the particles precipitate and are buried semi-permanently in the bottom sediment. Therefore, this adsorption reaction influences the concentration of dissolved silicate in the water column (Edwards and Liss 1973). In addition, this causes a gradual depletion of dissolved silicate in some lake waters (Tallberg 2000).

At Lake Nakaumi, a brackish lake located in western Japan, concentrations of dissolved silicate increase seasonally with total hydrogen sulfide in the anoxic hypolimnion and pore water in bottom sediment, which is characterized by elevated values (i.e., a maximum of $6.96 \mathrm{mmol} / \mathrm{L}$ ). These results suggest that dissolved silicate eluted from lake-bottom sediment in a highly anoxic-reducing environment.

In general, previous studies have proposed that dissolved silicate eluted from sediment originates from biogenic matter, such as diatom debris (van der Weijden 2007). However, Testa et al. (2013) noted that bacteria were not able to decompose diatom cell in an anoxic environment, and that elution of silicate adsorbed on ferric hydroxide would be main source for its supply to the pore water. In Lake Nakaumi, biogenic silica dissolution is also insufficient to explain the drastically increasing concentrations of silicate in an anoxic-reducing environment.

Silicate elution in reductive environments is considered to be one of the routes for the supply of silicate to a whole lake.
Dissolved silicates, which are eluted from sediment, diffuse into the hypolimnion and circulate throughout the entire lake via vertical mixing processes. Aquatic organisms can reuse this silicate as a nutrient source (Lehtimäki et al. 2016) or the silicate may react with metal oxides and re-precipitates in bottom sediments, such that sediment plays an important role as both source and sink for silicate (Matisoff et al. 1985). Additionally, we hypothesized that hydrogen sulfide affects the elution of silicate adsorbed on ferric hydroxide in an anoxic-reducing environment. In this study, we investigated the mechanisms of silicate adsorbed on ferric hydroxide and silicate elution in the presence of hydrogen sulfide in the laboratory experiments.

\section{Materials and methods}

\section{Sampling and chemical analysis}

\section{Sampling area and pretreatment for analysis}

We investigated a dredged area in Lake Nakaumi, a brackish lake with an average depth of $5.4 \mathrm{~m}$ that lies between Japan's Shimane and Tottori Prefectures (Fig. 1). In the 1960s, land reclamation projects here formed a dredged area with a maximum depth of approximately $17 \mathrm{~m}$. As a result, this area is often stagnant and has anoxic-reducing hypolimnion throughout the year (Sugahara et al. 2015).

Water samples were collected with Kitahara-type water sampler (Rigo, type 5023-B) in July and August 2015. Sampling was performed between depths of 1 and $15 \mathrm{~m}$ at $2 \mathrm{~m}$ intervals. Water temperature, redox potential, dissolved oxygen (DO) content, turbidity, electric conductivity, and

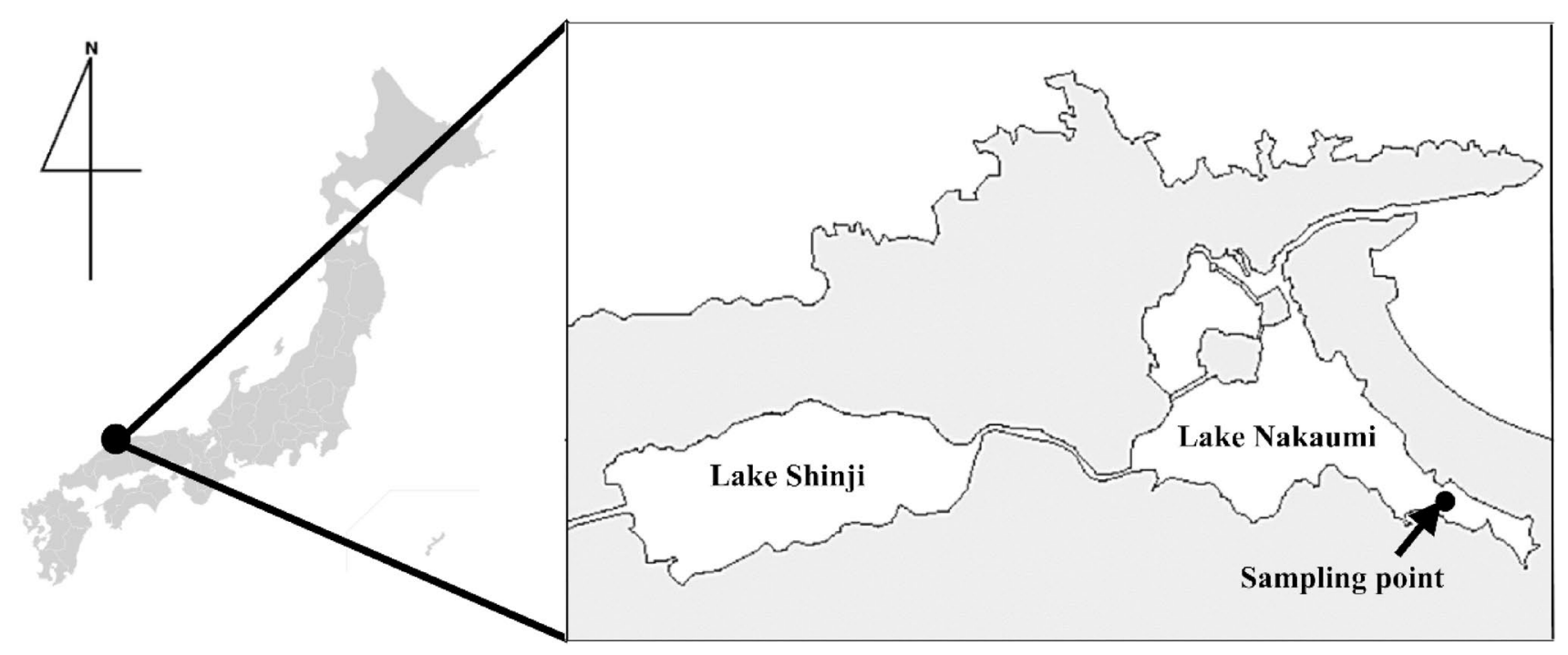

Fig. 1 Sampling point in Lake Nakaumi. The dredged area is located at $35.43^{\circ} \mathrm{N}, 133.27^{\circ} \mathrm{E}$ 
salinity were measured with a multi-water quality profiler (Hydrolab, Quanta and Datasonde5X). We measured $\mathrm{pH}$ with a pH meter (Horiba, type D-50).

Sediment cores were collected from the dredged area with a KK-type core sampler (diameter $=51 \mathrm{~mm}$, length $=670 \mathrm{~mm}$, Hashimoto Scientific Co., Ltd., Japan) in July 2015. All cores were sectioned into thicknesses of 1 or $2 \mathrm{~cm}$. A pore water sample was extracted from each section based on the methods reported in Sugahara et al. (2010). $2.5 \mathrm{~mL}$ of sediment from each section was placed into a $10 \mathrm{~mL}$ polyethylene syringe. Each sample was mixed with $2.5 \mathrm{~mL}$ of anaerobic deionized water prepared via bubbling nitrogen gas. A $25 \mathrm{~mm}$ filtering unit (pore size: $0.45 \mu \mathrm{m}$, Whatman) was then attached to the tip of the syringe to filter the mixture. The filtrate was analyzed for the dissolved silicate and other constituent concentrations. The actual $\left(C_{a}\right)$ and measured (in the filtrate; $C_{m}$ ) concentration were obtained using the following equations.

Water content $(W C, \%)$ of the wet sediment sample:

$W C=\frac{T W-D W}{T W} \times 100(\%)$

where $T W$ is the total weight of a wet $10 \mathrm{~mL}$ sediment sample (g), and $D W$ is the dry weight of a wet $10 \mathrm{~mL}$ sediment sample $(\mathrm{g})$. The pore water dilution ratio $(D R)$ in the syringe was calculated with the following equation:

$D R=\frac{\frac{W C}{100-W C} \times D W_{s}+2.5}{\frac{W C}{100-W C} \times D W_{s}}$

where $D W_{s}$ is the dry weight of the wet sediment sample collected in the syringe $(\mathrm{g})$. The actual concentration in the pore water was calculated as follows:

$C_{a}=C_{m} \times D R$

The dry weight was measured after drying the wet sediment sample at $105^{\circ} \mathrm{C}$ for $24 \mathrm{~h}$. The concentrations of phosphate $\left(\mathrm{PO}_{4}{ }^{3-}\right)$ and total hydrogen sulfide $\left(\mathrm{H}_{2} \mathrm{~S}+\mathrm{HS}^{-}\right)$were measured spectrophotometrically via the molybdenum blue $\left(\mathrm{PO}_{4}{ }^{3-}\right)$ and methylene blue methods $\left(\mathrm{H}_{2} \mathrm{~S}\right)$, respectively (Sugahara et al. 2010). Dissolved silicate was analyzed using the modified molybdenum yellow method as described in the following sections. Dissolved iron concentration was determined with inductively coupled plasma atomic emission spectrometer (ICP-AES, Optima 5000Z, Perkin-Elmer). All water samples were analyzed after filtration with a GF/F filter (Whatman, UK).

\section{Reagents}

Highly purified Milli-Q water (Millipore, Tokyo, Japan) was used to prepare chemical standard and reagent solutions.
Milli-Q water was also used to wash all bottles and experimental apparatus. All chemicals used were of guaranteed reagent grade.

A silicate standard solution $(16.6 \mathrm{mmol} / \mathrm{L}=1000 \mathrm{mg}$ $\mathrm{SiO}_{2} / \mathrm{L}$ ) was prepared by fusing $0.5 \mathrm{~g}$ of silicon dioxide with $5 \mathrm{~g}$ of sodium carbonate anhydrate and dissolving the pellet in $500 \mathrm{~mL}$ of Milli-Q water. An ammonium molybdate solution $(100 \mathrm{~g} / \mathrm{L})$ was obtained by dissolving ammonium heptamolybdate in Milli-Q water. A tartaric acid solution (200 $\mathrm{g} / \mathrm{L})$ was prepared by dissolving $\mathrm{L}+$-tartaric acid in Milli-Q water.

\section{Modified molybdenum yellow method for dissolved silicates}

Total hydrogen sulfide reduces a portion of the Mo (VI) ions in a molybdosilicate complex to Mo $(\mathrm{V})$, which changes its color from yellow to blue (Rich 2007). Total hydrogen sulfide is abundant in the anoxic bottom layer of a brackish lake. Lake Nakaumi's hypolimnion typically contains approximately $0.2 \mathrm{mmol} / \mathrm{L}$ of dissolved total hydrogen sulfide, whose concentration is elevated in the sediment (Sugahara et al. 2015). Therefore, appropriate pretreatment requires the complete removal of total hydrogen sulfide. The procedure for an accurate spectrophotometric determination of dissolved silicate was as follows. Lake water samples were filtered with a GF/F filter (Whatman, UK). $1 \mathrm{~mL}$ of $2.4 \mathrm{~mol} / \mathrm{L} \mathrm{HCl}$ was added to $20 \mathrm{~mL}$ of water sample in a polypropylene bottle, and total hydrogen sulfide in the sample was removed by stirring for $10 \mathrm{~min} .1 \mathrm{~mL}$ of $100 \mathrm{~g} / \mathrm{L}$ ammonium molybdate solution was then added to the sample. After $15 \mathrm{~min}, 1 \mathrm{~mL}$ of $200 \mathrm{~g} / \mathrm{L}$ tartaric acid solution was added to the mixture. After $5 \mathrm{~min}$, analyte solution absorbance was measured at $420 \mathrm{~nm}$ with a Shimadzu model UV-1800 spectrophotometer (Japan).

For pore water sample analysis, we modified the volumes of sample and reagent solutions. $4 \mathrm{~mL}$ of $0.12 \mathrm{~mol} / \mathrm{L} \mathrm{HCl}$ was added to $0.5 \mathrm{~mL}$ of the filtered pore water sample. Total hydrogen sulfide was removed by stirring for $10 \mathrm{~min}$. An ammonium molybdate solution $(100 \mathrm{~g} / \mathrm{L}, 0.25 \mathrm{~mL})$ was then added to the sample. After $15 \mathrm{~min}, 0.25 \mathrm{~mL}$ of a $200 \mathrm{~g} / \mathrm{L}$ tartaric acid solution was added to the mixture. Afterward, the procedures for sample treatment were identical to the lake water sample procedures.

\section{Laboratory experiments}

\section{Adsorption and elution of silicate onto ferric hydroxide precipitates}

Silicate and iron mixed solutions that contained $0.16 \mathrm{mmol} / \mathrm{L}$ $\mathrm{SiO}_{2}$ and 0 or $3.6 \mathrm{mmol} / \mathrm{L} \mathrm{FeCl}_{3}$ were prepared $(\mathrm{NaCl}$ concentration $=3.5 \%$ ). The solution $\mathrm{pH}$ was adjusted to 
$7.00 \pm 0.05$, which yielded a ferric hydroxide precipitate. After 1 day, $10 \mathrm{~mL}$ of the sample solution was filtered into a $50 \mathrm{~mL}$ polypropylene bottle with a $\mathrm{GF} / \mathrm{F}$ filter (filtrate A), and the ferric hydroxide precipitate was collected on the filter. The Si concentration in filtrate A was measured using the molybdenum yellow method. The ferric hydroxide precipitate was placed into another $50 \mathrm{~mL}$ polypropylene bottle and $10 \mathrm{~mL}$ of a $3.1 \mathrm{mmol} / \mathrm{L}$ sodium sulfide solution with a $\mathrm{pH}$ of 7 and $3.5 \% \mathrm{NaCl}$ was added to the precipitate. After standing for 1 day, the solution was filtered with a GF/F filter (filtrate B), and its Si concentration was also measured with the methods used for filtrate A.

\section{Silicate elution from bottom sediment with sodium sulfide solution}

In this experiment, we used sediment core samples at depths between 0 and $5 \mathrm{~cm}$ below the sediment surface. $35 \mathrm{~mL}$ of sediment sample was placed into a $50 \mathrm{~mL}$ polypropylene syringe. $15 \mathrm{~mL}$ of a sodium sulfide solution $(0,0.14$, and $8.8 \mathrm{mmol} / \mathrm{L}$ ) with a $\mathrm{pH}$ of 7 and $3.5 \% \mathrm{NaCl}$ was injected into the syringe. The tip of the syringe was sealed to prevent the entry of atmospheric air and was placed in a water bath at $20^{\circ} \mathrm{C}$ to inhibit airflow. After vigorous shaking for $10 \mathrm{~min}$, $1 \mathrm{~mL}$ of the filtrate was obtained from the mixture for $\mathrm{Si}$ concentration analyses.

\section{Results and discussion}

\section{Silicate concentrations in Lake Nakaumi}

In July 2015, the halocline was observed at 2-4 m depth with dissolved oxygen depletion in layers deeper than $4 \mathrm{~m}$ (Fig. 2). The redox potential had a negative value below depths of $10 \mathrm{~m}$. Total dissolved hydrogen sulfide was not detected in the epilimnion but increased with depth in the hypolimnion, where its concentration was $2.1 \times 10^{-1} \mathrm{mmol} / \mathrm{L}$ at the bottom $(15 \mathrm{~m})$ (Fig. 3). The vertical distribution profile of dissolved silicate also had similar patterns as the total hydrogen sulfide. The dissolved silicate concentration was nearly constant in the epilimnion and increased with depth in the hypolimnion, which was characterized by a concentration of $0.078 \mathrm{mmol} / \mathrm{L}$ at a depth of $15 \mathrm{~m}$.

The total hydrogen sulfide concentration in sediment had a maximum concentration of $5.83 \mathrm{mmol} / \mathrm{L}$ at $2.5 \mathrm{~cm}$ depth, which began to decrease below $4.5 \mathrm{~cm}$ depth and was not detected below $20 \mathrm{~cm}$ depth (Fig. 3). In the upper sediment $(0-2.5 \mathrm{~cm})$, the dissolved silicate concentration increased from 0.83 to $1.51 \mathrm{mmol} / \mathrm{L}$ with depth. Highly concentrated dissolved silicate $(3.29-3.86 \mathrm{mmol} / \mathrm{L})$ was detected below $15 \mathrm{~cm}$ depth. Dissolved iron concentrations were around the quantification limit by ICP-AES and reliable data were not obtained. Its concentration showed very low value of
Fig. 2 Vertical profiles of (a) water temperature (WT, $\square$ ) and salinity (open circle), and (b) dissolved oxygen $(\mathrm{DO}, \diamond)$ and redox potential (ORP, open triangle) in the water column in the dredged area of Lake Nakaumi for July 2015

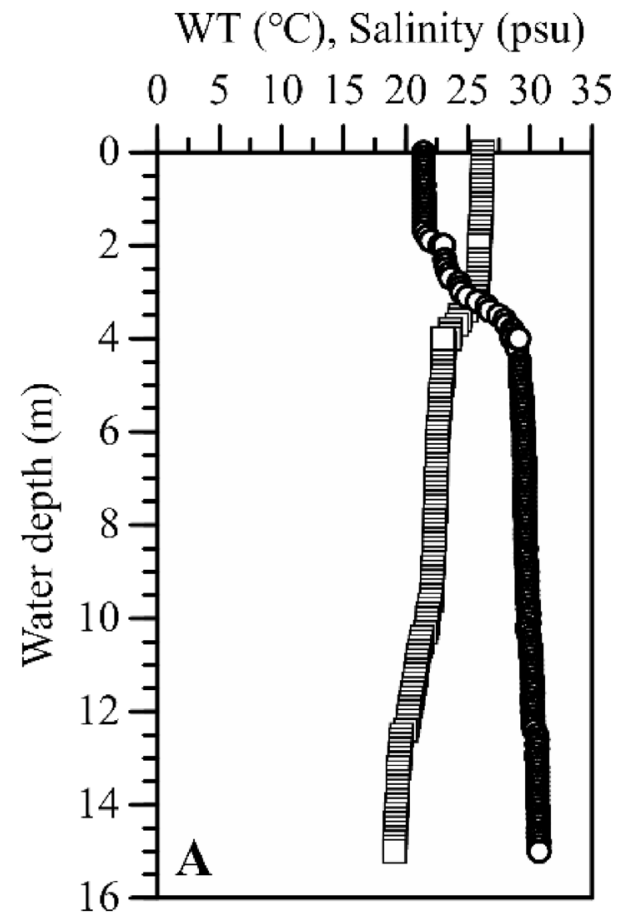


Fig. 3 Vertical profiles of total hydrogen sulfide (filled triangle), phosphate (filled rectangle), and dissolved silicate (open circle) in a the water column and $\mathbf{b}$ sediments in the dredged area of Lake Nakaumi for July 2015

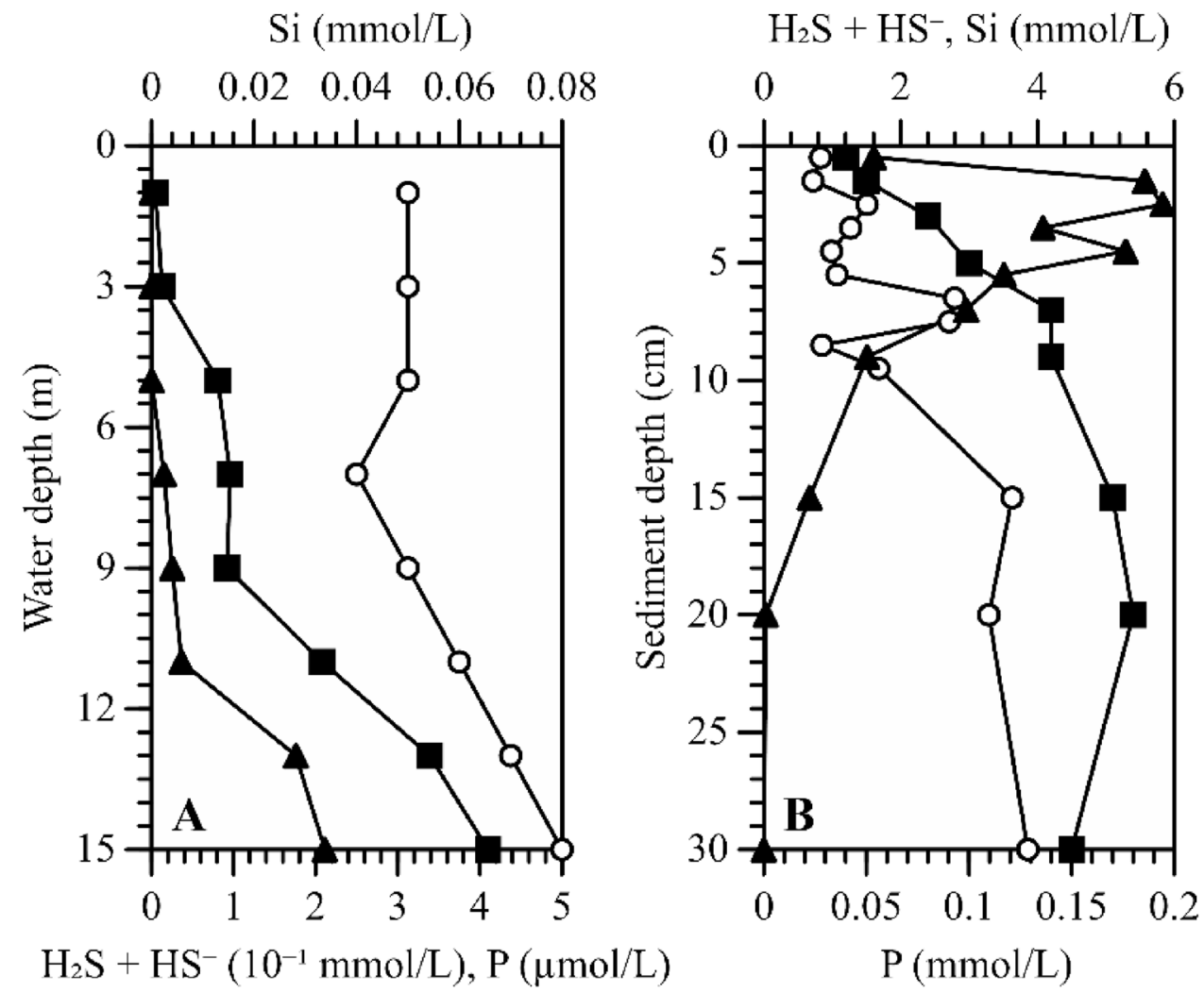

$0.07 \mathrm{nmol} / \mathrm{L}$ at the depth of $1.5 \mathrm{~cm}$ with total hydrogen sulfide of $5.57 \mathrm{mmol} / \mathrm{L}$. In August 2015, we observed even higher concentrations of dissolved silicate. Below $1.5 \mathrm{~cm}$ depth, the dissolved silicate concentration ranged from 3.25-6.96 $\mathrm{mmol} / \mathrm{L}$; the area weighted mean (4.22 $\mathrm{mmol} / \mathrm{L})$ was calculated from the vertically integrated silicate content based on the vertical distribution profile (Table 1). On the other hand, dissolved silicate concentration ranged $0.36-0.45 \mathrm{mmol} / \mathrm{L}$ in May 2015, and the area weighted mean was $0.41 \mathrm{mmol} / \mathrm{L}$. Dissolved silicate concentration increased from May to August in the pore water.

The existence of high concentrations of dissolved silicate in the pore water of Lake Nakaumi has not yet been reported. Concentrations in pore water of similar marine sediments have been reported as $0.08-0.13 \mathrm{mmol} / \mathrm{L}$ for the Bermuda Rise (Fanning and Pilson 1971) and 0.04-0.12 mmol/L for the Atlantic Ocean (Schink et al. 1975), significantly lower than that of Lake Nakaumi.

\section{Hypothesis regarding silicate elution in lake sediment}

In this study, silicate concentrations increased with those of total hydrogen sulfide in the anoxic hypolimnion and elevated concentrations of dissolved silicate were detected in pore water sampled from the bottom sediment in the dredged
Table 1 Concentration of silicates in the pore water in Lake Nakaumi sediments on 2015

\begin{tabular}{llll}
\hline Sediment depth $(\mathrm{cm})$ & $\begin{array}{l}\text { May } \\
\text { Si (mmol/L) }\end{array}$ & July & August \\
\hline 0.5 & 0.36 & 0.83 & 0.34 \\
1.5 & 0.36 & 0.72 & 4.01 \\
2.5 & 0.43 & 1.51 & 4.39 \\
3.5 & 0.43 & 1.27 & 3.92 \\
4.5 & 0.42 & 0.99 & 4.85 \\
5.5 & 0.40 & 1.07 & 6.96 \\
6.5 & 0.36 & 2.79 & 4.34 \\
7.5 & 0.41 & 2.71 & 3.25 \\
8.5 & 0.42 & 0.85 & 4.11 \\
9.5 & 0.45 & 1.68 & 4.86 \\
15.0 & 0.38 & 3.63 & 3.60 \\
20.0 & 0.45 & 3.29 & 3.77 \\
30.0 & & 3.86 & 5.10 \\
Area weighted mean* & 0.41 & 2.74 & 4.22 \\
\hline
\end{tabular}

*Area weighted mean was calculated from the vertically integrated silicate content

area of Lake Nakaumi; summer conditions enhanced this phenomenon.

Dissolved silicate adsorbs onto ferric hydroxide precipitates at neutral pH values (Iler 1979; Swedlund and Webster 
1999; Lehtimäki et al. 2016). In addition, ferric hydroxide is abundant in oxidative sediment found in brackish lakes along coastal sea areas (Kostka and Luther III 1994; Vigderovich et al. 2019). Based on this, we propose the following mechanisms as a hypothesis to explain the phenomenon observed in Lake Nakaumi. At oxidative conditions, iron exists as $\mathrm{Fe}^{3+}(\mathrm{III})$, forms ferric hydroxide $\left(\mathrm{Fe}(\mathrm{OH})_{3}\right)$, and precipitates in the bottom sediment. Then, dissolved silicate adsorbs onto ferric hydroxide. When bottom conditions change to anoxic, sulfate-reducing bacteria produce hydrogen sulfide. The newly-formed hydrogen sulfide reduces the ferric hydroxide, and the silicate within the hydroxide is eluted into the pore water. Ferrous iron, which forms via the reduction of ferric hydroxide, reacts with sulfide ions and ferrous sulfide precipitates in the hypolimnion and pore water. Okumura et al. (2009) reported that ferrous sulfide was saturated in the bottom layer of Lake Nakaumi. Since ferrous sulfide has an inferior affinity to silicate compared with ferric hydroxide (Philippini et al. 2006), eluted silicate does not adsorb onto ferrous sulfide and, subsequently, concentrates in the pore water.

Since seawater contains a large number of sulfate ions, sulfate reduction via microorganism activity occurs in the bottom layer of sea areas, even though there is not a complete depletion of dissolved oxygen. Rabalais et al. (2002) reported that sulfate reduction occurs when the dissolved oxygen concentration is less than $0.05 \mathrm{mg} / \mathrm{L}$. When sulfate reduction produces sulfide ions, this results in the reduction of ferric hydroxide. Previous studies have reported that ferric hydroxides coated with ferrous sulfide were present in marine sediments (Roden and Urrutia 2002). These reports indicate that our hypothesis may satisfy the conditions described above.
Borch et al. (2007) reported that ferric hydroxide, whose surface is coated with strongly adsorbed oxyanions such as phosphate, is difficult to be reduced by biological processes. Silicate's tetrahedral structure is the same as a phosphate molecule's, and its properties (such as an adsorption reaction to ferric hydroxide) are very similar. Therefore, ferric hydroxide adsorbing silicates may stably remain in a reducing environment because of their resistance to microbial diagenesis. Also, Lehtoranta et al. (2009) reported that lake eutrophication accelerates the conversion of dominant species from iron-reducing bacteria to sulfate-reducing bacteria, allowing for the production of hydrogen sulfide from the unfinished reduction of iron oxide. This idea is supported by previous studies on the reaction between ferric hydroxide and hydrogen sulfide in anoxic reducing sediments of the brackish lakes and the oceans (Canfield 1989; Fukusawa et al. 1995; Weston et al. 2006). Furthermore, Anschutz et al. (1998) reported that iron oxide existed in sediment where biological sulfate reduction was progressing, and Thamdrup et al. (1994) reported that amorphous iron (III) coexisted with hydrogen sulfide below $5 \mathrm{~cm}$ sediment depth, indicating an anoxic environment. Therefore, iron reduction in the anoxic-reducing sediment of Lake Nakaumi may be caused by hydrogen sulfide because this is known to be a eutrophic lake with a hypoxic water layer (Kusunoki and Sakata 2018) and dissolved silicate concentrations in the pore water exceeded the solubility of diatoms in the same condition.

Consequently, we suggest that silicate adsorbed onto ferric hydroxide is eluted by a reaction between hydrogen sulfide and ferric hydroxide in an anoxic-reducing environment. As shown in Fig. 4. In the oxidative condition, dissolved silicate adsorbed onto ferric hydroxide, and this matter is accumulated in sediment. When the lake-bottom
Fig. 4 Behavior of dissolved silicate with a change in a lakebottom environment
Oxidative condition $\quad$ Anoxic-reducing condition

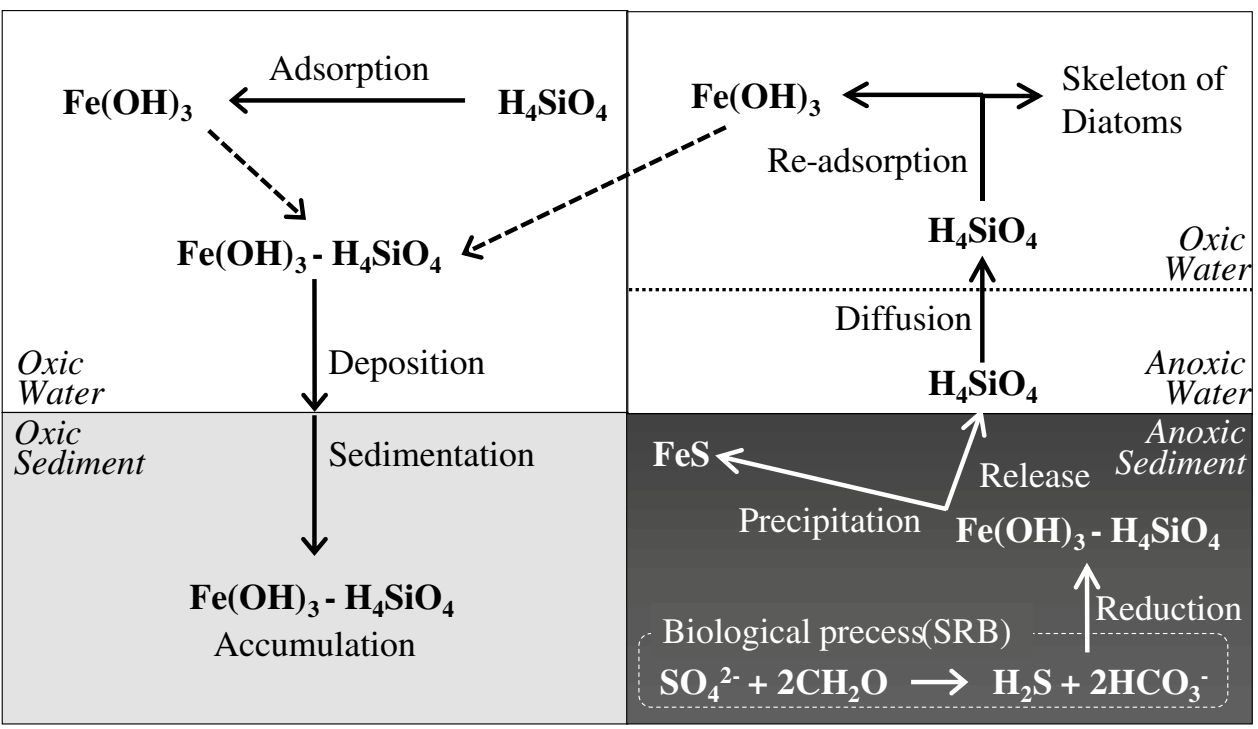


environment was changed to an anoxic-reducing condition, hydrosulfide (: $\mathrm{HS}^{-}$, and also hydrogen sulfide) was produced by a sulfate-reducing bacteria (SRB) and react with ferric hydroxide adsorbing silicate. As a result, ferric iron was reduced to the black iron sulfide (ferrous sulfide), at the same time, silicate was released in the water.

\section{Adsorption and elution of silicate onto ferric hydroxide in laboratory experiments}

In the silicate and dissolved iron mixed solution, the dissolved silicate concentration in filtrate A collected after the adsorption experiment noticeably decreased with an increase in the iron concentration. The adsorbed silicate fraction was nearly $80 \%$ at the iron concentration $(3.6 \mathrm{mmol} / \mathrm{L})$ (Fig. 5). This result indicates that silicate is efficiently adsorbed onto ferric hydroxide at neutral $\mathrm{pH}$ values.

The precipitate (ferric hydroxide) collected on the filter was placed into $10 \mathrm{~mL}$ of a $3.1 \mathrm{mmol} / \mathrm{L}$ sodium sulfide solution $(\mathrm{pH}=7.0)$, whose color changed from brown to dark gray. This result suggests that ferric hydroxide was reduced to ferrous ion by the addition of sodium sulfide and that ferrous sulfide was formed by the reaction between ferrous ions and bisulfide ions remaining in the solution.

Filtrate B was collected from a mixed solution of precipitate and sodium sulfide after standing for $10 \mathrm{~min}$, after which the Si concentration in the filtrate was measured. Figure 6 shows the concentrations of silicate in filtrates A and $\mathrm{B}$. The sum of the Si concentrations in the two filtrates was equal to $94 \%$ and $93 \%$ of the initial Si concentration $(0.16 \mathrm{mmol} / \mathrm{L})$ during the adsorption experiments at iron concentrations of 0.54 and $1.80 \mathrm{mmol} / \mathrm{L}$, respectively. The silicate concentrations in filtrate $\mathrm{B}$, i.e., the concentration of Si eluted from the ferric hydroxide precipitate by adding the sodium sulfide solution, were $82 \%$ and $92 \%$ of the adsorbed

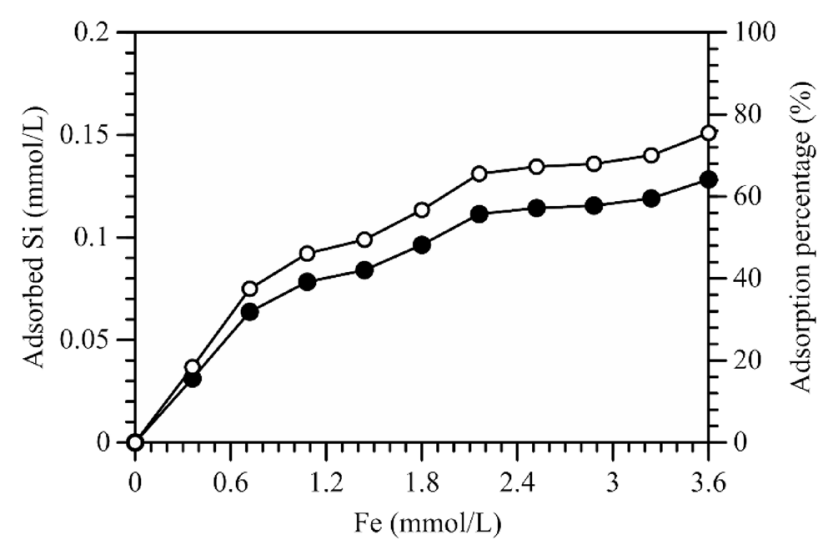

Fig. 5 Adsorption of silicate onto ferric hydroxide precipitate for the concentration of adsorbed silicate (filled circle) and percentage of silicate adsorbed (open circle). The initial silicate concentration was $0.16 \mathrm{mmol} / \mathrm{L} ; \mathrm{pH}$ of each solution was adjusted to $7.00 \pm 0.05$

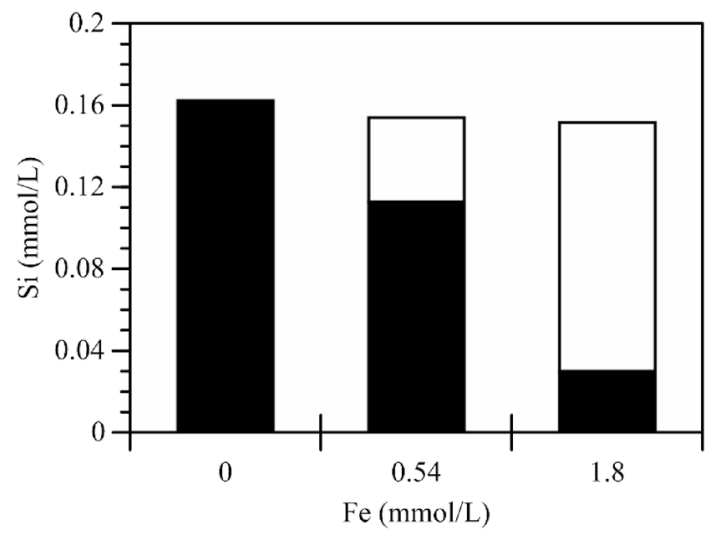

Fig. 6 Elution of the silicate adsorbed onto ferric hydroxide upon the addition of sodium sulfide. Results for filtrate A (concentration of silicate not adsorbed onto ferric hydroxide) shown in black; results for filtrate B (concentration of silicate eluted from ferric hydroxide by the addition of sodium sulfide) shown in white

silicate (the difference between the initial concentration of $0.16 \mathrm{mmol} / \mathrm{L}$ and the concentration in filtrate $\mathrm{A}$ ), respectively. These results agree with our hypothesis that silicate is eluted from the ferric hydroxide during its reaction with sulfide ions as we already explained in the former section using Fig. 4.

\section{Silicate elution from Lake Nakaumi bottom sediment based on laboratory experiments}

We examined the elution of silicate from sediment core samples collected from Lake Nakaumi by adding a sodium sulfide solution. The concentrations of dissolved silicate eluted from sediment increased with increasing sodium sulfide concentrations (Fig. 7). We also detected the silicate

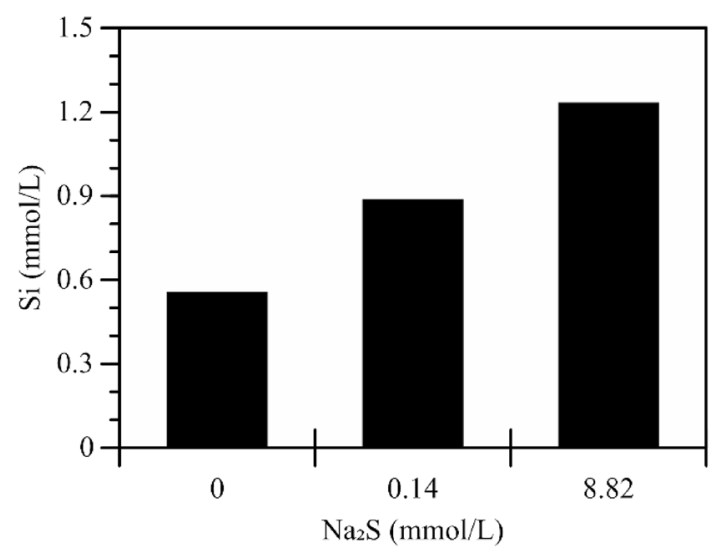

Fig. 7 The amount of silicate eluted when sodium sulfide was added to the anoxic sediments collected from Lake Nakaumi, based on sample depth of $0-5 \mathrm{~cm}$ and $\mathrm{pH}$ of 6.94 . The result was obtained at 10 min after adding the sodium sulfide solution, respectively 
concentration by adding a solution without sodium sulfide because the sediment originally contained sulfide ions. However, the addition of sodium sulfide $(8.8 \mathrm{mmol} / \mathrm{L})$ increased the silicate concentration twofold from its level at $0 \mathrm{mmol} / \mathrm{L}$. These results suggest that silicate, which was eluted to pore water from ferric hydroxide, remained in the bottom sediments due to hydroxide reduction via sulfide ions.

\section{Other sources of dissolved silicate in pore water}

In addition to ferric hydroxide adsorbing a great deal of silicate, biogenic silica is also a possible source of dissolved silicate in pore water (Van der Weijden 2007). However, Rickert et al. (2002) reported that the solubility of biogenic silica was about $1.4 \mathrm{mmol} / \mathrm{L}$ at a water temperature of $14{ }^{\circ} \mathrm{C}$ (this temperature is the average sediment temperature of Lake Nakaumi in the summer), which is much lower than the maximum concentration observed in Lake Nakaumi. In addition, the sediments are characterized by a decline in biogenic silica dissolution rate, and differences in dissolution rate based on the presence or absence of oxygen are relatively small (Lehtimäki et al. 2016). Rickert et al. (2002) also reported that inorganic and organic materials coat the surface of biogenic silica in sediments. These coatings significantly reduce its dissolution rate, which indicates that the complete dissolution of biogenic silica in sediment to pore or bottom water requires approximately 100 years (Hurd 1973). Furthermore, Testa et al. (2013) reported that biogenic silicate was not decomposed in an anoxic-reducing sediment because of bacteria's inability to decompose diatom cell walls. Thus, biogenic silica may not contribute to the highly concentrated dissolved silicate and its rapid dissolution during the short periods that are applicable to this study of Lake Nakaumi.

\begin{abstract}
Acknowledgements We wish to express our sincere gratitude to Prof. Masahito Sugiyama, Kyoto University. His guidance and support have been invaluable to this study. The other experiments and analyses were mainly performed in the environmental analytical chemistry laboratory at the Interdisciplinary Graduate School of Science and Engineering, Shimane University. We wish to thank our many colleagues at Shimane University for their scientific collaborations.
\end{abstract}

Open Access This article is licensed under a Creative Commons Attribution 4.0 International License, which permits use, sharing, adaptation, distribution and reproduction in any medium or format, as long as you give appropriate credit to the original author(s) and the source, provide a link to the Creative Commons licence, and indicate if changes were made. The images or other third party material in this article are included in the article's Creative Commons licence, unless indicated otherwise in a credit line to the material. If material is not included in the article's Creative Commons licence and your intended use is not permitted by statutory regulation or exceeds the permitted use, you will need to obtain permission directly from the copyright holder. To view a copy of this licence, visit http://creativecommons.org/licenses/by/4.0/.

\section{References}

Anschutz P, Zhong S, Sundby B, Mucci A, Gobeil C (1998) Burial efficiency of phosphorus and the geochemistry of iron in continental margin sediments. Limnol Oceanogr 43:53-64. https://doi. org/10.4319/lo.1998.43.1.0053

Borch T, Masue Y, Kukkadapu R, Fendorf S (2007) Phosphate imposed limitations on biological reduction and alteration of ferrihydrite. Environ Sci Technol 41:166-172. https://doi.org/10.1021/es060 $695 \mathrm{p}$

Canfield DE (1989) Reactive iron in marine sediments. Geochim Cosmochim Acta 53:619-632

Conley D (1997) Riverine contribution of biogenic silica to the oceanic silica budget. Limnol Oceanogr 42:774-777. https://doi. org/10.4319/lo.1997.42.4.0774

Conley D, Schelske C, Stoermer E (1993) Modification of the biogeochemical cycle of silica with eutrophication. Mar Ecol Prog Ser 101:179-192

Edwards A, Liss P (1973) Evidence for buffering of dissolved silicon in fresh waters. Nature 243:341-342

Fanning K, Pilson M (1971) Interstitial silica and $\mathrm{pH}$ in marine sediment: some effects of sampling procedures. Science 173:12281231. https://doi.org/10.1126/science.173.4003.1228

Fischer W, Knoll A (2009) An iron shuttle for deepwater silica in Late Archean and early Paleoproterozoic iron formation. Bull Geol Soc Am 121:222-235. https://doi.org/10.1130/B26328.1

Fukusawa H, Koizumi I, Okamura M, Yasuda Y (1995) Last 2,000 year records of Eolian dust concentration sea-level and precipitation changes in fine-grained sediment of Lake Suigetsu, Central Japan. J Geogr 104:69-81

Furumai H (2012) Monitoring of silicic acid and research implication. In: Furumai H, Sato K, Yamamoto K (ed) Silicic acid, its source and transportation. Gihodo, p 165-176.

Gottlieb M, Meyers P (2012) Method of removing and recovering silica using modified ion exchange materials. p 1-12.

Hallmark C, Wilding L, Smeck N (1982) Silicon. In: Page A, Miller R, Keeney D (eds) Methods of soil analysis, Part 2: chemical and microbiological properties. American Society of Agronomy, Soil Science Society of America, pp 263-273

Hurd D (1973) Interactions of biogenic opal, sediment and seawater in the Central Equatorial Pacific. Geo Et Cos Acta 37:2257-2282. https://doi.org/10.1016/0016-7037(73)90103-8

Iler RK (1979) Polymerization of silica. In: Iler RK (ed) The chemistry of silica: solubility, polymerization, colloid and surface properties and biochemistry of silica. Wiley, New Jersey, pp 172-204

Kostka JE, Luther GW III (1994) Partitioning and speciation of solid phase iron in saltmarsh sediments. Geochim Cosmochim Acta 58:1701-1710

Kusunoki K, Sakata M (2018) Analysis of historical trend of eutrophication in Lake Nakaumi, Japan, using concentrations of several index elements in sediment cores (in Japanese). J. JSWE 41:151157. https://doi.org/10.2965/jswe.41.151

Lacombe M, Garçon V, Comtat M, Oriol L, Sudre J, Thouron D, Le Bris N, Provost C (2007) Silicate determination in sea water toward a reagentless electrochemical method. Mar Chem 106:489-497. https://doi.org/10.1016/j.marchem.2007.05.002

Lehtimäki M, Sinkko H, Tallberg P (2016) The role of oxygen conditions in the microbial dissolution of biogenic silica under brackish conditions. Biogeochemistry 129:355-371. https://doi. org/10.1007/s10533-016-0237-1

Lehtoranta J, Ekholm P, Pitkänen H (2009) Coastal eutrophication thresholds: a matter of sediment microbial processes. Ambio 38:303-308. https://doi.org/10.1579/09-A-656.1

Matisoff G, Fisher B, Matis S (1985) Effects of benthic macroinvertebrates on the exchange of solutes between sediments and 
freshwater. Hydrobiologia 122:19-33. https://doi.org/10.1007/ BF00018956

Officer C, Ryther J (1980) The possible importance of silicon in marine eutrophication. Mar Ecol Prog Ser 3:83-91

Okumura M, Anata T, Seike Y (2009) The behavior of iron(II) and hydrogen sulfide in anoxic brackish lake water. Int Verh Internat Verein Limnol 30:1107-1110. https://doi.org/10.1080/03680 770.2009 .11902312

Perry C, Keeling-Tucker T (2000) Biosilicification: the role of the organic matrix in structure control. J Biol Inorg Chem 5:537-550

Philippini V, Naveau A, Catalette H, Leclercq S (2006) Sorption of silicon on magnetite and other corrosion products of iron. J Nucl Mat 348:60-69. https://doi.org/10.1016/j.jnucmat.2005.09.002

Rabalais N, Turner E, Wiseman W (2002) Gulf of Mexico hypoxia, a.k.a. "The dead zone". Annu Rev Ecol Syst 33:235-263. https:// doi.org/10.1146/annurev.ecolsys.33.010802.150513

Rich R (2007) Molybdenum, 42Mo; Tungsten, 74W and Seaborglum, 106Sg. In: Rich R (ed) Inorganic reactions in water. Springer, Berlin, pp 136-138

Rickert D, Schlüter M, Wallmann K (2002) Dissolution kinetics of biogenic silica from the water column to the sediments. Geo Et Cos Acta 66:439-455. https://doi.org/10.1016/S0016-7037(01)00757 $-8$

Roden E, Urrutia M (2002) Influence of biogenic Fe(II) on bacterial crystalline Fe(III) oxide reduction. Geomicrobiol J 19:209-251. https://doi.org/10.1080/01490450252864280

Schelske C, Stoermer E (1971) Eutrophication, silica depletion, and predicted changes in algal quality in Lake Michigan. Science 173:423-424. https://doi.org/10.1126/science.173.3995.423

Schink D, Guinasso N, Fanning K (1975) Processes affecting the concentration of silica at the sediment-water interface of the Atlantic Ocean. J Geophys Res 80:3013-3031. https://doi.org/10.1029/ JC080i021p03013

Sugahara S, Yurimoto T, Ayukawa K, Kimoto K, Senga Y, Okumura M, Seike Y (2010) A simple in situ extraction method for dissolved sulfide in sandy mud sediments followed by spectrophotometric determination and its application to the bottom sediment at the Northeast of Ariake Bay. Bunseki Kagaku 59:1155-1161. https://doi.org/10.2116/bunsekikagaku.59.1155

Sugahara S, Kamiya H, Suyama Y, Senga Y, Ayukawa K, Okumura M, Seike Y (2015) Influence of hypersaturated dissolved oxygenated water on the elution of hydrogen sulfide and methane from sediment in the dredged area in polyhaline Lake Nakaumi. Landsc Ecol Eng 11:269-282

Swedlund P, Webster J (1999) Adsorption and polymerization of silicic acid on ferrihydrite, and its effect on arsenic adsorption. Water
Res 33:3413-3422. https://doi.org/10.1016/S0043-1354(99)00055 $-X$

Tallberg P (2000) Silicon and its impacts on phosphorus in eutrophic freshwater lakes. University of Helsinki, Finland

Testa J, Brady D, Di Toro D, Boynton W, Cornwell J, Kemp M (2013) Sediment flux modeling: simulating nitrogen, phosphorus, and silica cycles. Estuar Coast Shelf S 131:245-263. https://doi. org/10.1016/j.ecss.2013.06.014

Thamdrup B, Fossing H, Jørgensen BB (1994) Manganese, iron, and sulfur cycling in a coastal marine sediment, Aarhus Bay, Denmark. Geochim Cosmochim Acta 58:5115-5129. https://doi. org/10.1016/0016-7037(94)90298-4

Tréguer P, Nelson MD, Van Bennekom AJ, DeMaster DJ, Leynaert A, Quéguiner B (1995) The silica balance in the world ocean: a reestimate. Science 268:375-379. https://doi.org/10.1126/scien ce.268.5209.375

Van der Weijden C (2007) Silica I: Silicon analytical, physical, and terrestrial geochemistry. Utrecht University, Netherlands, Department of Geosciences-Geochemistry

Vempati R, Loeppert R (1989) Influence of structural and adsorbed Si on the transformation of synthetic ferrihydrite. Clay Clay Miner 37:273-279. https://doi.org/10.1346/CCMN.1989.0370312

Vigderovich H, Liang L, Herut B, Wang F, Wurgaft E, Rubin-Blum M, Sivan O (2019) Evidence for microbial iron reduction in the methanic sediments of the oligotrophic southeastern Mediterranean continental shelf. Biogeosciences 16:3165-3181. https://doi. org/10.5194/bg-16-3165-2019

Weston NB, Dixon RE, Jaye SB (2006) Ramifications of increased salinity in tidal freshwater sediments: Geochemistry and microbial pathways of organic matter mineralization. J Geophys Res 111:1-14. https://doi.org/10.1029/2005JG000071

Willén E (1991) Planktonic diatoms-an ecological review. Arch Hydrobiol 62:69-106

Yee N, Phoenix V, Konhauser K, Benning L, Ferris G (2003) The effect of cyanobacteria on silica precipitation at neutral $\mathrm{pH}$ : implications for bacterial silicification in geothermal hot springs. Chem Geol 199:83-90

Publisher's Note Springer Nature remains neutral with regard to jurisdictional claims in published maps and institutional affiliations. 